\title{
Hedgehog Family
}

National Cancer Institute

\section{Source}

National Cancer Institute. Hedgehog Family. NCI Thesaurus. Code C120493.

A family of extracellular proteins that act as signaling molecules and regulate embryonic patterning events during development. They are synthesized as inactive precursors with an $\mathrm{N}$-terminal signaling domain linked to a C-terminal autoprocessing domain, which has a structure that resembles intein protein splicing domains. 